GRZEGORZ BLICHARZ (Kraków)

\title{
Prawne aspekty finansowania transportu morskiego w starożytnym Rzymie
}

\section{Pożyczka morska - spojrzenie w przeszłość i w przyszłość? Pożycz-} ka morska (pecunia traiecticia) to ciagle aktualne dziedzictwo prawa rzymskiego. Lokuje się ona raczej na obrzeżach siatki pojęciowej wypracowanej w ramach prawa prywatnego, a obecnie budzi zainteresowanie tylko dosyć wąskiej grupy naukowców. Jest przedmiotem analizy romanistów, historyków prawa, często przywołuje się ją we wstępach historycznych do prac z zakresu ubezpieczeń gospodarczych. Stanowi także wdzięczny temat dla ekonomistów, badających dawne instrumenty finansowe. Wszystko wydaje się wskazywać, że każdy, kto chciałby zgłębiać rzymską pożyczkę morską, zmuszony jest do przyjęcia wyłącznie metody historycznoprawnej i perspektywy ukierunkowanej na to, co było. Przynajmniej taka droga była najczęściej wybierana w XX i XXI wieku. Rodzi się jednak wątpliwość, czy pozwala ona na uzyskanie możliwie najpełniejszego obrazu pecunia traiecticia w dotychczasowej nauce prawa.

Obok szerokiego wglądu w historię tej pożyczki, najbardziej istotne staje się wskazanie celów i wartości, jakie już starożytni prawnicy uznali za wymagające ochrony i stworzenia instrumentu do ich realizacji. Podjęte poszukiwania powodowane są nasuwającymi się pytaniami o charakter rzymskiej pożyczki morskiej, o potrzebę społeczną leżącą u podstaw korzystania z tej umowy. Zrozumienie funkcji, którą pełniła pecunia traiecticia będzie sprzyjało szerszej refleksji nad podobieństwem rozwiązań przyjętych w rzymskiej myśli prawnej i w prawie współczesnym. Jednocześnie należy się zastanowić, czy pożyczka morska była inspiracją dla prawa prywatnego, czy pozostaje nią również dzisiaj. A jeśli nie, czy oznacza to jej śmierć, czy raczej zasadne jest oczekiwać, że ponownie odrodzi się i zacznie być wykorzystywana w dzisiejszych lub przyszłych czasach?

Pecunia traiecticia była umową, w której wierzyciel przenosił na dłużnika własność pieniędzy, które następnie miały zostać zainwestowane w transport morski: żeglarz musiał albo przewieźć przez morze otrzymane środki finansowe 
w celu zakupu dóbr, albo przetransportować towary nabyte za te pieniądze. Jeśli żegluga nie powiodła się i dłużnik nie zdołał dotrzeć do portu przeznaczenia, obowiązek oddania pożyczki ustawał. Całkowite przejęcie przez wierzyciela ryzyka podróży stanowiło zatem najbardziej charakterystyczny rys pecunia traiecticia $^{1}$. Natomiast, jeżeli transport morski zakończył się szczęśliwie, finansujący mógł spodziewać się oprócz oddania pożyczonej kwoty, znacznego zysku w postaci odsetek, których wysokość do czasów Justyniana była nieograniczona, a od konstytucji cesarskiej z $528 \mathrm{r}$. wynosiła centesimae, tj. 12,5\%, czyli znacznie większy procent niż dozwolony wówczas ze zwykłej pożyczki (mutuum) ${ }^{2}$.

Tak wygląda najbardziej ogólny opis umowy pożyczki morskiej. Zadaniem niniejszej pracy będzie przedstawienie charakterystyki rzymskiej pecunia traiecticia, tj. okoliczności i kontekstu, w których się nią posługiwano.

\section{Przedmiot umowy pożyczki morskiej. Nazwa pecunia traiecticia po-} wszechnie pojawia się w tekstach jurystów rzymskich przynajmniej od czasów Serwiusza Sulpicjusza Rufusa (D. 22,2,8), czyli od I w. przed Chr. Pecunia traiecticia to dosłownie pieniądze przeznaczone do transportu, do przerzucenia ich - w domyśle w inne miejsce, co rozumiano jako przeprawienie ich przez morze. Oznaczają one pożyczkę morską, przez co nie przesądza się jednak, czy mowa o odrębnym kontrakcie od pożyczki ${ }^{3}$. Dopiero justyniańscy kompilatorzy zdecydowali się na zmianę tego zwyczaju językowego i wprowadzili do użycia nazwę fenus nauticum, którą umieścili w tytułach „Digestów”, „Kodeksu” i „Nowel”, traktujących o pożyczce morskiej ${ }^{4}$. Choć dosłownie należałoby ją przetłumaczyć jako „odsetki morskie” lub „zysk morski”, zgodnie z zachodnią tradycją prawną od czasów średniowiecza aż po XIX w. uważa się to za synonim określenia pecunia traiecticia, który stał się o wiele bardziej znany niż oryginalna nazwa ${ }^{5}$. Wyrażenie fenus nauticum podkreśla szczególną rolę odsetek, które kompilatorom justyniańskim najwyraźniej kojarzyły się najbardziej z pożyczką morską i stanowią jej pierwszą cechę. Nie bez przyczyny również większość jurystów, przy temacie odsetek, omawia także tę pożyczkę. Nato-

\footnotetext{
${ }^{1}$ Franciszek Longchamps de Bérier, Czyżby już starożytni Rzymianie...? 'Pecunia traiecticia', „Przegląd Ubezpieczeń Społecznych i Gospodarczych” 8/1997, s. 2.

${ }^{2}$ Wojciech Dajczak, Tomasz Giaro, Franciszek Longchamps de Bérier, Prawo rzymskie. U podstaw prawa prywatnego, Warszawa 2009, s. 517.

${ }^{3} \mathrm{~W}$ innym wypadku może dojść do niejasnych tłumaczeń źródeł, jak np. w dziewiętnastowiecznym angielskim thumaczeniu The Digest or Pandects of Justinian, t. 5, thum. Samuel P. Scott, Cincinnati 1932, s. 222 - D. 22,2,1: Money is transported which is carried across the sea.

${ }^{4}$ Wiesław Litewski, Römisches Seedarlehen, „Iura” 24/1973, s. 115, wskazuje, że nazwa fenus nauticum została użyta tylko jeden raz przed czasami justyniańskimi, a to przez cesarza Dioklecjana w konstytucji C. 4,33,4 (między 286 i 294 r. po Chr.), ale oznaczała rzeczywiście tylko odsetki - fenus, nie zaś umowę pożyczki morskiej.

${ }^{5}$ Por. Janusz Sondel, Stownik łacińsko-polski dla prawników i historyków, Kraków 2001, s. 377, s.v. fenus.
} 
miast sformułowanie traiecticia używane przez nich wskazuje na jej drugą cechę, że dotyczyć ma tego, co przewożone, transportowane przez morze. Tytuł drugi księgi 22 „Digestów” - De nautico faenore, zawierający największy materiał źródłowy na temat pożyczki morskiej, rozpoczyna definicja Modestyna, zaczerpnięta z jego „Pandektów”.

\section{22,2,1 (Modestinus libro decimo pandectarum): Traiecticia ea pecunia est} quae trans mare vehitur: ceterum si eodem consumatur, non erit traiecticia.

Pożyczkę morską stanowi ta, która przez morze jest wieziona. W przeciwnym razie, jeśli w tym samym miejscu zostanie wykorzystana, nie będzie morską.

Definicja Modestyna nosi znamiona typowego zdania analitycznego, które nie wykracza treściowo poza językową postać swojego definiendum, w tym wypadku nazwę pecunia traiecticia. Za kluczowy element pożyczki morskiej zostaje zatem uznany transport pieniędzy przez morze. Przynajmniej taka jej postać wydaje się juryście najbardziej intuicyjna. Nie wyczerpuje to wszelako zakreślonych przez niego granic pożyczki, co widać jeszcze w tym samym fragmencie, zaczerpniętym przez kompilatorów justyniańskich z jego „Pandektów”:

Sed videndum, an merces ex ea pecunia comparatae in ea causa habentur? et interest, utrum etiam ipsae periculo creditoris navigent: tunc enim traiecticia pecunia fit.

Lecz czy jest oczywiste, że towary nabyte z tej pożyczki zostaną utrzymane w takim stanie? Ważne jest, czy rzeczywiście płyną na ryzyko samego wierzyciela. Wtedy mianowicie [taka pożyczka] staje się pożyczką morską.

Może pojawić się wątpliwość, czy prezentowany przez Modestyna tok rozumowania odzwierciedla historyczny rozwój interpretacji pożyczki morskiej, czy też jest sposobem przedstawiania zagadnienia prawnego: od rozumienia stricte językowego do bardziej funkcjonalnego ${ }^{6}$. Pewne jest jednak, że w opinii prawnika z III w. po Chr. i kompilatorów justyniańskich przedmiot pożyczki morskiej obejmuje zarówno pieniądze, jak i towary nabyte $z$ uprzednio otrzymanych pieniędzy. Jurysta w swojej odpowiedzi zauważa, że kluczowe są trzy kwestie: po pierwsze - przedmiot pożyczki (pieniądze lub towary) ma być transportowany przez morze; po drugie - wierzyciel musi przyjąć na siebie ryzyko żeglugi; po

${ }^{6}$ Postawienie pytania nie musi sugerować, że Modestyn miał do czynienia z kazusem prawnym, który przyniósł rozszerzenie zastosowania pożyczki morskiej dopiero w III w. po Chr. Może być to środek dyskursywny użyty przez Modestyna dla jaśniejszego wyłożenia problemu. Por. W. Litewski, Römisches..., s. 121, przyp. 47. Kontekst palingenetyczny nie okazuje się pomocny w rozwiązaniu tej wątpliwości, gdyż powyższy fragment został umieszczony w księdze bez tytułu, w której pomieszane są bardzo różne kwestie. Por. Otto Lenel, Palingenesia Iuris Civilis, t. 1, Lipsiae 1889, s. 725, s.v. Modestinus nr 136. 
trzecie - jeśli płyną towary, to koniecznie te zakupione z udzielonej pożyczki morskiej. Zatem posiada ona zawsze charakter pieniężny. Spośród wskazanych przesłanek, najważniejszą dla jurysty wydaje się przejęcie ryzyka przez wierzyciela. Nie wolno oczywiście zapominać o dwóch pozostałych. Konieczność przewiezienia przez morze oraz obowiązek, aby towary pochodziły z pożyczonych pieniędzy, wskazują, iż celem staje się ich inwestycja. Dla Rzymian zaczyna liczyć się sposób, w jaki udzielona pożyczka zostanie spożytkowana. Zatem wykorzystanie jej w tym samym miejscu, uniemożliwia zakwalifikowanie jako pożyczki morskiej, tylko wtedy, gdy nie nabyto za nią towarów do transportu zamorskiego lub w istocie nie zostały one przewiezione statkiem. Taki zakres zastosowania pożyczki morskiej był niewątpliwie ważny dla wymiany handlowej i stanowił udogodnienie zachęcające do eksportowania towarów.

Przyjęcie literalnego rozumienia pecunia traiecticia - możliwość przewozu samych tylko pieniędzy - nie sprzyjałoby handlowi morskiemu, gdyż pozwalałoby na korzystanie z pożyczki morskiej tylko przy imporcie towarów ${ }^{7}$. Tymczasem możliwość przewożenia morzem na ryzyko wierzyciela już nie tylko środków płatniczych, ale także zakupionych towarów przyspieszała obrót handlowy, gdyż eksport stawał się mniej ryzykowny, a ponadto pojawiała się okazja do spekulacji towarami przez grę wahaniami cen wywożonych i przywożonych dóbr ${ }^{8}$. Dzięki pożyczce morskiej kupcy i inwestorzy na pewno chętniej prowadzili handel morski. W innym wypadku trudno wyobrazić sobie, aby obok „eksportu pieniędzy” z ograniczonym ryzykiem funkcjonował eksport towarów z pełnym ryzykiem po stronie transportujących morzem. Dla racjonalnego wykorzystania możliwości handlowych zasadne było jednoczesne współistnienie obu sposobów korzystania z pożyczki morskiej. Wątpliwości w tej mierze nasuwają się wszelako pod wpływem lektury pochodzącej z przełomu V i VI wieku po Chr. interpretacji Pauli Sententiae, dokonanej w Lex Romana Wisigothorum:

ad PS. 2,14,3: Traiecticia pecunia dicitur, quae in navi, ut ad transmarina deferatur, deponitur quia maris periculo committitur, in quantas convenerit usuras, hanc pecuniam dare creditor potest.

Pożyczką morską nazywa się tę, którą na statku złożono, aby została przewieziona przez morze; ponieważ ryzyko morskie jest przejęte, wierzyciel może dać te pieniądze na taki odsetek, jaki tylko zostanie umówiony.

${ }^{7}$ Por. W. Litewski, Römisches..., s. 122-123, gdzie autor przyjmuje, że tekst Modestyna odzwierciedla historyczny rozwój pożyczki morskiej oraz że u swoich początków pożyczka ta miała służyć wyłącznie importowi towarów.

${ }^{8}$ Dlatego trudno zgodzić się z teza, że Modestyn czy kompilatorzy justyniańscy mogli traktować towarowy charakter pożyczki morskiej w kategoriach wyjątku, por. Z. Benincasa, 'Periculi pretiumi'. Prawne aspekty ryzyka zwiazanego z podróżami morskimi $w$ Starożytnym Rzymie (II $w$. p.n.e.-II w. n.e.), Warszawa 2011, s. 121-122, przyp. 240. 
W literaturze przedmiotu można dziś spotkać się z tezą, opartą na powyższym fragmencie, iż literalna wykładnia pożyczki morskiej była charakterystyczna nie tylko dla dawnych czasów, lecz w pewien sposób powróciła również $\mathrm{w}$ prawie wulgarnym ${ }^{9}$. Z brzmienia samego tekstu nie wynika jednak w sposób oczywisty, że za pożyczkę morską złożoną na statku, mają być rozumiane tylko pieniądze. Użyte zostało przecież sformułowanie traiecticia pecunia, które należy traktować jako nazwę własną - ,pożyczka morska”, a nie „pieniądze przewożone”. Wspomnienie środków pieniężnych wynika z tego, że pierwotnie każda pożyczka morska udzielana jest w pieniądzu, ale to nie decyduje, co ostatecznie zostanie złożone na pokładzie statku. Wymienione obowiązki przewiezienia przez morze i przejęcia ryzyka przez wierzyciela potwierdzają tylko, że również w prawie wulgarnym pozostało niezmienione dogmatyczne pojmowanie znaczenia przesłanek pożyczki morskiej.

Wszystko wskazuje na to, że tekst Modestyna jest zgrabnym opisem charakteru pożyczki morskiej, aktualnym również w czasach justyniańskich kompilatorów, którzy umieścili go na samym początku tytułu, aby wyraźnie określić, jakie są granice jej zastosowania ${ }^{10}$. Trudno uznać odpowiedź na pytanie sed vindendum ... za rozstrzygnięcie, które mogło być przełomowe dla stosunków gospodarczych Rzymu, zwłaszcza że pochodzi dopiero z III w. po Chr., a zatem wydaje się, że nie oddaje historycznego rozwoju pożyczki morskiej. W dostępnych dzisiaj źródłach rzymskich problem przedmiotu tej pożyczki więcej się nie pojawia i przekaz Modestyna należy uznać za powszechnie akceptowany, przynajmniej w prawie justyniańskim i wśród cytowanych jurystów okresu klasycznego. Umieszczono go na pierwszym miejscu w tytule $D e$ nautico faenore, przez co należy przyjąć, że raczej w tym okresie nie był kontrowersyjną lub nietypową opinią. W dziewiętnastowiecznej i dwudziestowiecznej romanistyce miała jednak miejsce dyskusja na temat wąskiej i szerokiej interpretacji terminu pecunia traiecticia ${ }^{11}$. Zastanawiano się, czy przedmiotem

\footnotetext{
${ }^{9}$ Por. W. Litewski, Römisches..., s. 121.
}

${ }^{10}$ Ibidem, s. 123.

${ }^{11}$ Por. Z. Benincasa, Periculi..., s. 121 oraz przyp. 240, gdzie autorka szczegółowo omawia stanowiska prezentowane w literaturze. Zwolennikiem zawężającej interpretacji był Francesco De Martino, który pod pojęciem pecunia chciał rozumieć tylko pieniądze, co nie zostało zaakceptowane przez większość autorów (por. W. Litewski, Römisches..., s. 121; Ugo Enrico Paoli, Studi di diritto attico, Firenze 1930, s. 41, 49; Fritz Pringsheim, Der Kauf mit fremdem Geld, Leipzig 1916, s. 143). W literaturze romanistycznej przeważa zdecydowanie rozszerzająca interpretacja, a jedynie - jak podaje autorka - Karl Visky uważał, że istniały dwie formy pożyczki, w zależności, od tego, co stanowiło przedmiot, natomiast Giorgio Campanino wskazywał, że nabyte towary były tylko wyjątkowo przedmiotem pożyczki. Pogląd F. De Martino wynikał z poszukiwania kształtu pożyczki morskiej w klasycznym prawie rzymskim. Główny argumentem był zarzut justyniańskiej interpolacji we fragmencie Modestyna, polegający na dodaniu rozważań o towarach nabytych za pożyczkę. Świadczyć ma o tym użycie ,interest, utrum”. F. De Martino rozumie utrum jako odmianę uter (obydwaj, który z dwóch, każdy z dwóch) i uważa, że interpolacja miałaby polegać na wycięciu pewnego fragmentu, gdyż tekst nie omawia żadnego innego przypadku oprócz towarów nabytych. Sprzeciwili się 
pożyczki morskiej mogły być zarówno pieniądze, jak i towary nabyte za nie, czy też wyłącznie środki pieniężne. Rozważania te mogły wydawać się nie intuicyjne, biorąc pod uwagę fragment z Modestyna. $Z$ kolei próba sprowadzenia pożyczki morskiej tylko do przewożenia pieniędzy mijała się z charakterem tej umowy.

Oczywiście takie spory zrodziły się nie bez przyczyny, a ich powodem był nie tylko popularny swego czasu ,argument z interpolacji”. Inny sposób interpretacji fragmentu Modestyna zasadza się na założeniu, że jurysta zadaje pytanie nie o towar nabyty w tym samym miejscu, w którym udzielono pożyczki, ale o towar zakupiony już po przewiezieniu pieniędzy ${ }^{12}$. Zatem, przedmiotem umowy byłby zawsze transport pieniędzy, a jeśli wierzyciel zgodziłby się, uprzednio lub następczo, mógłby przejąć ryzyko utraty, płynących z powrotem dóbr nabytych za te pieniądze. Są dwa słabe punkty tego podejścia. Po pierwsze - uznaje ono, że istotą pożyczki morskiej nie jest przewożenie pieniędzy, ale ponoszenie ryzyka przez wierzyciela, dlatego dopuszcza pożyczkę morską w formie towarowej. Po drugie - niezrozumiałe może się wydać, dlaczego taka możliwość miałaby ograniczać się tylko do kursu w jedną stronę. Nie przemawiają za tym ani racje ekonomiczne, ani prawne. Ponadto źródła potwierdzają praktykę realizowania pożyczki morskiej już w porcie macierzystym i transportowania towarów, a nie pieniędzy. Ważnym przekazem zdaje się w tym zakresie „kazus morski”, opisany przez Scewolę w księdze 28 jego „Digestów”:

D. 45,1,122 (Scaevola libro vicensimo octavo digestorum): Callimachus mutuam pecuniam nauticam accepit a Sticho servo Seii in provincia Syria civitate Beryto usque Brentesium: idque creditum esse in omnes navigii dies ducentos, sub pignoribus et hypothecis mercibus a Beryto comparatis et Brentesium perferendis et quas Brentesio empturus esset et per navem Beryto invecturus...

Kalimach przyjął udzieloną pożyczkę morską od Stichusa, niewolnika Seiusa, w mieście Bejrucie w prowincji Syrii [na podróż] aż do Brindisi. I pożyczono na wszystkie 200 dni żeglugi, pod zastawami i hipotekami na towarach, które kupiliście w Bejrucie i które mają być przewiezione do Brindisi i tych, które byłyby zakupione w Brindisi i statkiem sprowadzone do Bejrutu...

temu Arnaldo Biscardi i Wiesław Litewski. Ten ostatni podnosi, że utrum jest po prostu pewnym skrótem, który odnosi się do towarów i do wcześniej omawianego transportowania pieniędzy, co potwierdzają słowa ea causa. Natomiast A. Biscardi podnosi, iż wielokrotnie w źródłach spotyka się wyrażenie interest utrum, oznaczające jako całość: „ważne jest to, że”. Drugą interpolację wskazuje jednak sam A. Biscardi i uważa za nią fragment „sed videndum...habentur”. Ma to być glosa, która rozdziela wywód Modestyna. Sprzeciwia się temu W. Litewski, uznając, że równie dobrze mógł być to zabieg dydaktyczny samego jurysty. A. Biscardi nie odrzuca jednak z tego powodu towarowego charakteru pożyczki. Por. W. Litewski, Römisches..., s. 121-128, przyp. 47, 48.

12 Por. Bernhard Matthiass, Das 'foenus nauticum' und die geschichtliche Entwicklung der Bodmerei, Würzburg 1881, s. 16 i nn. 
W tekście nie powiedziano wprost, że nabyte w Bejrucie towary pochodzą z otrzymanych pieniędzy. Fakt jednak, że jako zastaw zostały wybrane właśnie te towary oraz towary, które mają przybyć na tym statku, nie wydaje się przypadkowy. Podobna praktykę potwierdza również fragment autorstwa Paulusa z księgi 25 jego „Kwestii”:

D. 22,2,6 (Paulus libro vicesimo quinto quaestionum): Faenerator pecuniam usuris maritimis mutuam dando quasdam merces in nave pignori accepit...

Wierzyciel dał pieniądze pożyczone na odsetki morskie i przyjął w zastaw pewne towary na statku...

Pomocną okazuje się także konstytucja cesarzy Dioklecjana i Maksymiana, wydana między 286 i 294 r. po Chr., skierowana do Aurelii Iuliany, która dotąd budzi wiele kontrowersji w literaturze, jeśli chodzi o właściwe odczytanie stanu faktycznego. Źródła nie pozwalają jednoznacznie rozstrzygnąć tej wątpliwości. Wydaje się, że może dotyczyć omawianego powyżej problemu.

C. 4,33,4 (Diocletianus et Maximianus Aurealiae Iulianae.): Cum proponas te nauticum fenus ea condicione dedisse, ut post navigium, quod in Africa dirigi debitor adseverabat, in Salonitanorum portum nave delata fenebris pecunia tibi redderetur, ita ut navigii dumtaxat quod in Africam destinabatur periculum susceperis, perque vitium debitoris, nec loco quidem navigii servato, illicitis comparatis mercibus quae navis continebat fiscum occupasse: amissarum mercium detrimentum, quod non ex marinae tempestatis discrimine, sed ex praecipiti avaritia et incivili debitoribus audacia accidisse adseveratur, adscribi tibi iuris publici ratio non permittit.

Skoro przedstawiasz, że pożyczka morska została dana pod warunkiem, iż po żegludze, którą do Afryki dłużnik będzie kierował i strzegł, w porcie Salona przekazane na procent pieniądze tobie gorliwie zwróci, tak żebyś przyjął na siebie ryzyko tylko tej żeglugi, która do Afryki została skierowana, [z powodu] bardzo złej wiary dłużnika, który na pewno nie dopilnował miejsca docelowego żeglugi, bezprawnie nabyte towary, które były trzymane na statku, zostały zajęte przez skarb cesarski. Straty towaru z powodu szkody, która nie wynikła z burzy morskiej, lecz $\mathrm{z}$ popadnięcia $\mathrm{w}$ chciwość i gdy zaobserwowano, że doszło do sprzecznej ze słusznością zuchwałości dłużnika, racja prawa publicznego nie pozwala na przypisanie tobie.

Konstytucja opisuje sytuację, w której dłużnik przyjął pieniężną pożyczkę morską w porcie Salona (dzisiejszy Solin w Chorwacji), gdzie nabył towary, tyle że, nielegalne. Miał płynąć do Afryki, ale zboczył z trasy, żeby uniknąć zajęcia towarów. Przedstawiciele skarbu cesarskiego jednak zdołali go zatrzy- 
mać i zarekwirowali nielegalne dobra, które przewoził na statku. Musiały one być zakupione z pożyczki morskiej. W innym wypadku, dlaczego rozważane miałoby być ryzyko wierzyciela? Cesarze podkreślili, że ryzyko to musi dotyczyć sytuacji niezawinionych przez dłużnika, kwalifikowanych ponadto jako wynikające $z$ siły wyższej. W omawianym kazusie strata towaru powstałaby bezpośrednio na skutek chciwości i zuchwałości dłużnika. Z drugiej strony ciekawe wydaje się pytanie, gdyby towar został rzeczywiście stracony w burzy morskiej, czy wierzyciel mógłby domagać się zwrotu pożyczki, argumentując, że towary te były nabyte niezgodnie z prawem lub że ich posiadanie było nielegalne. Jeżeli rodzaj towaru, który miał być zakupiony, stanowił istotne podmiotowo postanowienie umowy, można byłoby dochodzić zwrotu pożyczki. Dzięki przekazowi Scewoli, który pochodzi z tekstu, cytowanego częściowo powyżej (D. 45,1,122), wiadomo, że każde naruszenie umowy przez dłużnika, jak zmiana trasy czy niezakupienie w terminie towarów - a zatem, przypuszczalnie również kupno nie tych towarów lub kupno wbrew zasadom prawa mogło rodzić odpowiedzialność z tytułu kary umownej, czyli stipulatio poene. Zastrzegano ją, aby wymusić na dłużniku przestrzeganie porozumienia, a stawała się należna na podstawie domniemania, że warunek umowy się spełnił.

D. 45,1,122 (Scaevola libro vicensimo octavo digestorum): ...convenitque inter eos, uti, cum Callimachus Brentesium pervenisset, inde intra idus Septembres, quae tunc proximae futurae essent, aliis mercibus emptis et in navem mercis ipse [receptis $]^{13}$ in Syriam per navigium proficiscatur, aut, si intra diem supra scriptam non reparasset merces nec enavigasset de ea civitate, redderet universam continuo pecuniam quasi perfecto navigo et praestaret sumptus omnes prosequentibus eam pecuniam, ut in urbem Romam eam deportarent.

I jest postanowione między nimi, że kiedy Kallimach przybędzie do Brindisi, stamtąd przed upływem najbliższych przyszłych id wrześniowych, które wtedy byłyby, z innymi towarami nabytymi i z towarem [przyjętym] na statek, sam statkiem wyruszyłyby do Syrii, lub, jeśli przed upływem terminu powyżej zapisanego nie zakupiłby towaru ani nie wypłynąłby z powrotem z tego miasta, oddałby natychmiast całą pożyczkę, jak gdyby podróż zakończyła się i świadczyłby wydatki wszystkich, którzy podążali za tą pożyczką, i dostarczyłyby ją do miasta Rzymu.

Powyższy, jak i wcześniejszy fragment przytoczony przez kompilatorów justyniańskich z dzieła Scewoli, wyraźnie potwierdzają, że pożyczka morska mogła polegać wyłącznie na przewozie towarów. Z zacytowanego tekstu wynika, że Seius pożyczył pieniądze Kallimachowi, który kupił za nie towary w Bejrucie. Następnie przetransportował do Brindisi, gdzie je sprzedał.

${ }^{13}$ Uzupełnienie Theodora Mommsena należy uznać za zasadne i zgodne z formą gramatyczną tego fragmentu. 
Z otrzymanych pieniędzy miał zakupić nowe towary, które powinny były zostać przewiezione do Bejrutu. Mógł również przyjąć na statek nowy towar, prawdopodobnie jako nową pożyczkę morską - być może od innego niewolnika upoważnionego przez Seiusa. Niewolnik ten mógł być jego przedstawicielem w Brindisi. Istnienie rozbudowanej sieci handlowej jest pewną hipotezą, lecz wydaje się, że tak mógł wyglądać bardziej rozwinięty rynek pożyczek morskich, w których podstawą była gra wahaniami cen różnych towarów, w zależności od rozpoznanego popytu w określonych częściach cesarstwa.

Z punktu widzenia bezpieczeństwa wierzyciela, ustanowienie zastawu umownego na towarach przewożonych przez morze, który chroniłby wierzytelność główną z pożyczki morskiej, nie wydaje się czymś rozsądnym. Zastanawia, dlaczego wierzyciele ustanawiali zastawy właśnie na swego rodzaju substracie pożyczki, narażonym przecież na ryzyko podróży morskiej, a nie przyjmowali zabezpieczenia na innych, stabilniejszych, składnikach majątku dłużnika, które pozostawałyby na lądzie. Wydaje się, że w umowie pożyczki morskiej przenoszone na wierzyciela było nie tylko ryzyko samego transportu, ale również niebezpieczeństwo związane z utratą przewożonych towarów. Można postawić hipotezę, że nawet jeżeli podróż zakończyła się szczę́liwie, lecz przewożone towary utracono na skutek siły wyższej, szkodę ponosił wierzyciel. Nie mógł się on wtedy domagać zwrotu pożyczki. Wniosek taki nasuwa się na podstawie lektury cytowanej już konstytucji Dioklecjana i Maksymiana:

Straty towaru z powodu szkody, która nie wynikła z burzy morskiej, lecz z popadnięcia w chciwość i gdy zaobserwowano, że doszło do sprzecznej ze słusznością zuchwałości dłużnika, racja prawa publicznego nie pozwala na przypisanie tobie.

Wyjaśnienie powodów i użyteczności tej praktyki zależeć będzie od rozpoznania, jaką rolę odgrywało „szczęśliwe dopłynięcie statku”, a jaką „szczę́sliwe dowiezienie towaru". Będzie to mogło nastapić dopiero po ustaleniu w dalszej części pracy, jakie ryzyko przejmował wierzyciel przy pożyczce morskiej. Na razie trzeba przynajmniej wskazać na związek prawny i ekonomiczny między pożyczonymi pieniędzmi, zakupionymi towarami oraz towarami, na których ustanawiano zastaw.

Dwoisty, pieniężny i towarowy, charakter pożyczki morskiej bezdyskusyjnie przyjęto w średniowiecznych, w nowożytnych glosach oraz komentarzach do tekstu Modestyna. Akursjusz wyjaśniał, że pecunia oznacza rzecz, którą się posiada ze względu na pożyczkę morska, tak że przepada ona na ryzyko wierzyciela ${ }^{14}$. Cujacjusz uznawał, że pożyczka morska może być realizowana

${ }^{14}$ Corpus Iuris Civilis Iustinianei, cum Commentariis Accursii, Scholiis Contii, et D. Gothofredi lucublationibus ad Accursium, in quibus Glossae obscuriores explicantur, similes \& contratiae asse- 
również w towarach nabytych za pożyczone pieniądze, jeśli ryzyko utraty towarów przyjął na siebie wierzyciel ${ }^{15}$. Vivianus wskazywał podobnie - tj. jeśli za otrzymane pieniądze kupi się w tym samym miejscu towar i przewiezie przez morze, a ryzyko będzie po stronie wierzyciela, należy uznać, że jest to pożyczka morska ${ }^{16}$. Również nauka usus modernus w osobie Johannesa Voeta przyjmowała za oczywiste, iż do pożyczki morskiej dochodzi wtedy, gdy pieniądze lub towary są przewożone na ryzyko wierzyciela ${ }^{17}$. W przeciwieństwie jednak do czasów starożytnych rozszerzyła stosowanie pecunia traiecticia również na transport lądowy i nazwała taką umowę fenus quasi nauticum. Jako argument za wprowadzeniem takiej ciekawej innowacji podawano, iż ryzyko napadu wrogów lub rozbójników na lądzie jest wystarczające dla korzystania $\mathrm{z}$ reguł pożyczki morskiej ${ }^{18}$.

Jeszcze bardziej elastyczne podejście do przedmiotu pożyczki morskiej charakteryzuje tradycję common law. W sprawie John Conard v. The Atlantic Insurance Company New York jedna ze stron podnosiła, że istotnym rozróżnieniem, dokonanym przez Modestyna, nie jest to, czy dobra przewożone zostały nabyte z pożyczki czy nie, lecz to, czy były transportowane na ryzyko wierzyciela $^{19}$. Przypisywanie juryście takiej dystynkcji stało jednak w sprzeczności z zawartym we fragmencie „Digestów” obowiązkiem nabycia towarów z tej pożyczki. Zaś argument strony polegał na wyjęciu z kontekstu samego zakończenia powyższego tekstu, w którym dopuszcza się pożyczkę morską na towarach, pod warunkiem przejęcia ryzyka ich transportu. Posłużono się nim w sporze dotyczącym pożyczki respondentia, wywodzącej się z tradycji pecunia traiecticia. Amerykański Sąd Najwyższy odciął się jednak od rzymskich korzeni prawa angielskiego, rozstrzygając spór na korzyść wspomnianej strony, choć wątpliwy argument z „Digestów” nie miał decydującego znaczenia. Sąd

runtur, vitiosa notantur. Tomus hic Primus Digestum Vetus continet, Lugduni, 1627, s. 2049: „e Pecunia. id est res habentur pro pecunia traiectitia, ut sic pereat periculo creditoris".

${ }^{15}$ Ibidem: „, Utrum etiam ipsae. Traiectitia pecunia est, quae navigat periculo creditoris, et merces etiam ex ea coparatae, si mercium periculum creditor susceperit. Cuiac".

${ }^{16}$ Digestum Vetus seu Pandectarum Iuris civilis tomus pirmius. Ex Pandectiis Florentinis, quae olim Pisanae dicebantur, quoad eius fieri potuit, repraesentatus: Commentariis Accursii, et multorum insuper aliorum tam veterum quŕm neoteoricorum Iureconsultorum scholiis atque observationibus illustratus, Parisiis 1566, apud Gulielmum Merlin in ponte Numulariorum, et Gulielmum Desboys sub Sole aureo, ac Sebastianum Nivellium sub Ciconiis, via Iacobea, s. 2066: „Secundo pone quod mutuo tibi centum aureos, ut emas merces hic, et portes ultra mare. Quaeritur, an haec merces sint traiecticiae, ut sic possim usuram pacisci? Et respondeo, si actum est, ut meo periculo sint, sic: alias non. Vivianus". Ta interpretacja wyraźnie sprzeciwia się rozumieniu fragmentu Modestyna przyjętemu przez B. Matthiassa.

17 Johannes Voet, Lugundo-batava commentarius ad Pandectas, t. 1, Coloniae 1778, s. 768: „1. Nauticum foenus est, quod ex pecuniam vel merce alienave re trajectitiam seu transmare vehendam periculo creditoris, penditur atque etiam ex pacto peti potest".

${ }^{18}$ Ibidem, s. 768-769.

${ }^{19}$ John Conard v. The Atlantic Insurance Company New York, 26 U.S. 386, 1 Pet. 386, 7 L.Ed. 189, January Term, 1828, par. 114-116, 254. 
skorzystał z poszanowania zasady dobrej wiary i całkowicie rozluźnił wymogi wypracowane w rzymskiej myśli prawnej. Stwierdzono, że jeśli umowa nie prowadzi do czystej spekulacji lub obejścia prawa, to można udzielać pożyczki respondentia również, gdy nie zostanie ona zainwestowana w przewożony towar. Zatem mogła mieć miejsce już po tym, jak statek wypłynął z portu, w czasie żeglugi, natomiast ani wyposażenie statku, ani towary umieszczone na nim i wystawione na ryzyko wierzyciela nie musiały pochodzić z pożyczonych pieniędzy.

III. Nieograniczona wysokość odsetek przy pożyczce morskiej? Z dotychczasowych rozważań wynika, że pożyczka morska służyła jako podstawowy instrument prawny dla handlu morskiego w starożytnym Rzymie. Korzystano z niej w relacjach między organizującymi transport statkami a inwestorami, którzy poprzez przeznaczanie pieniędzy na określone zazwyczaj z góry towary, z jednej strony liczyli na własny, i to duży, zysk, a z drugiej umożliwiali zarobek żeglarzom. Tym dochodem wierzycieli były odsetki. Obok przedmiotu umowy pożyczka morska - co ujawnia się już w nazwie fenus nauticum charakteryzowała się właśnie uprzywilejowanymi co do wysokości odsetkami. Pauli Sententiae w tytule XIV De usuris podają:

PS. 2,14,3: Traiecticia pecunia propter periculum creditoris, quamdiu navigat navis, infintas usuras recipere potest.

Przy pożyczce morskiej ze względu na ryzyko wierzyciela, jak długo statek płynie, można pobierać nieskończone odsetki.

W cytowanym już wcześniej komentarzu do tego fragmentu, pochodzącym z Lex Romana Wisigothorum, podtrzymano, że wysokość odsetek zależy tylko od woli stron ${ }^{20}$. Było to wyjątkowe uprzywilejowanie, gdyż w pozostałych przypadkach, wedle świadectwa Pauli Sententiae, dopuszczano odsetki tylko do $1 \%$ miesięcznie (centesimae), czyli 12\% rocznie ${ }^{21}$. Co więcej, historia prawa rzymskiego zna raczej nieustanne walki z pobieraniem wysokich odsetek lub próby ich całkowitego zakazania, niż przyzwalanie i to na nielimitowana ich wysokość. Prawdopodobnie pierwsze postanowienia ograniczające stawki odsetek znalazły się już w ustawie XII tablic, a na pewno zawierała je lex Duilia Menenia z 357 r. przed Chr., która być może powtarzała wcześniejsze regulacje. Granica odsetek ustanowiona została wówczas na fenus unciarium $(1 / 12)$. Do tej pory nie jest jednak rozstrzygnięte, za jaki okres „dwunasta

${ }^{20}$ ad PS. 2,14,3 ...quia maris periculo committitur, in quantas convenerit usuras, hanc pecuniam dare creditor potest.

${ }^{21}$ PS. 2,14,2: Usurae supra centesimam solutae sortem minuunt, consumpta sorte repeti possunt. 
część" miała być naliczana. Zgodnie z dwoma najpoważniejszymi stanowiskami Rzymianie brali pod uwagę albo stosunek roczny albo miesięczny. W pierwszym przypadku koszt pożyczki wynosiłby $12 \%$ sumy głównej, zaś w drugim 100\%. W roku 347 przed Chr., nieznanym z nazwy plebiscytem, obniżono dopuszczalną granicę o połowę (semiuncia), a w 342 r. przed Chr. wprowadzono całkowity zakaz udzielania oprocentowanych pożyczek, zawarty w lex Genucia. Treść tej ustawy również budzi wątpliwości, a szczególnie sformułowanie versura. Jego analiza prowadzi do prawdopodobnego wniosku, że w ustawie chodziło raczej o zakaz anatocyzmu ${ }^{22}$. W celu ukróceniu jego obchodzenia uchwalono jeszcze lex Sempronia w 193 r. przed Chr. oraz lex Marcia, które jednak nie przyniosły spodziewanych efektów. W republice kwestia politycznej i prawnej dopuszczalności odsetek i ich wysokości była stale obecna ${ }^{23}$. U schyłku wprowadzono natomiast nowy sposób naliczania odsetek centesima pars sortis, czyli 12\% w stosunku rocznym (miesięcznie 1 as od 100 asów pożyczki), które były wymagalne w każde kalendy. Ponadto, opierając się na reformach Lukullusa, namiestnika Azji Mniejszej z ok. 70 r. przed Chr., wprowadzono ograniczenie wysokości odsetek do centesimae, czyli $12 \%$ w stosunku rocznym ${ }^{24}$. O nich mówi cytowany wcześniej fragment PS. 2,14,2.

Biorąc pod uwagę tak podejrzliwe podejście prawodawców do kwestii odsetek, tym bardziej zaskakuje zniesienie wszelkich granic w przypadku pożyczki morskiej. Wydaje się, idąc za argumentacją z Pauli Sententiae, że fundamentalnym uzasadnieniem był niezwykle ryzykowny charakter pożyczki morskiej dla wierzyciela. Dopiero Justynian, w konstytucji z 528 r., wprowadził nowe maksymalne stawki odsetek, dzieląc je na 4 rodzaje: dla osób znamienitych $4 \%$ rocznie, dla rzemieślników i innych prowadzących legalną działalność $8 \%$ rocznie, dla pozostałych $6 \% \mathrm{w}$ skali roku. Natomiast w przypadku pożyczki morskiej postanowił:

C. 4,32,26,2 (Imp. Iustinianus A. Menae pp.): ...in traiecticiis autem contractibus vel specierum fenori dationibus usque ad centesimam tantummodo licere stipulari nec eam excedere, licet veteribus legibus hoc erat concessum... (528 r.)

Natomiast w umowach [odnośnie] transportu morskiego lub o dane na odsetek gatunki [rzeczy oznaczone gatunkowo] aż do centesimae ${ }^{25}$ jedynie dozwolone jest

${ }^{22}$ Anna Pikulska-Robaszkiewicz, Lichwa w państwie i prawie republikańskiego Rzymu, Łódź 1999, s. 60-61.

${ }^{23}$ Por. W. Dajczak, T. Giaro, F. Longchamps de Bérier, Prawo rzymskie..., s. 492.

${ }^{24}$ Por. A. Pikulska-Robaszkiewicz, Lichwa ..., s. 67.

${ }^{25}$ Od czasów Konstantyna centesimae jest liczona jako 12,5\% rocznie. Stało się to po reformie monetarnej, od której zaczęto liczyć odsetki, zgodnie z greckim zwyczajem, w stosunku rocznym, a nie miesięcznym, tj. 3 sykle przypadały na 1 solida, solid zawierał 24 sykle, co daje $1 / 8$ głównej sumy, czyli $12,5 \%$. Rzymianie, nie mając wygodniejszego sposobu wyrażenia tej liczby, używali jako jej zamiennika dawnej centesimae, oznaczającej wcześniej 12\%. Por. hasło „fenus” w: A Dictio- 
stypulować i nie można ich przekroczyć, chociaż było to przyznane przez dawne prawa.

Cesarz zdecydował się na przełamanie dotychczasowej tradycji. Jak stwierdził w tej samej konstytucji, ograniczenie wysokości odsetek wynikało z konieczności zmiany dotychczasowych praw, które były zbyt surowe i nakładały na dłużników zbyt duże obciążenia. Nadal jednak uznawano za racjonalne utrzymanie uprzywilejowania odsetek od pożyczek morskich. Warto zaznaczyć, że tę samą pozycję miały tylko odsetki od pożyczek udzielanych w naturze (zbożu itp.) zaciągane przez rolników, co zostało potwierdzone Nowelami 32, 33 i 34. Wydaje się zatem, że spośród pożyczek pieniężnych, tylko pecunia traiecticia utrzymała tak wysoki stopień zwrotu ${ }^{26}$.

IV. Przejmowanie ryzyka przez pożyczkodawcę. Jak już wspomniano za Pauli Sententiae możliwość pobierania nieograniczonych w swej wysokości odsetek zależała od tego, czy wierzyciel brał ryzyko na siebie, czy też nie. Potwierdzają to liczne fragmenty „Digestów” i „Kodeksu”.

D. 22,2,4 (Papinianus libro tertio responsorum): Nihil interest, traiecticia pecunia sine periculo creditoris accepta sit an post diem praestitutum et condicionem impletam periculum esse creditoris desierit. utrubique igitur maius $<$ legitima $>$ usura faenus non debebitur, sed in priore quidem specie semper, in altera vero discusso periculo: nec pignora vel hypothecae titulo maioris usurae tenebuntur.

Nie ma różnicy, czy pożyczka morska będzie zawarta bez ryzyka po stronie wierzyciela, czy też ryzyko wierzyciela ustało po wyznaczonym dniu i po spełnieniu warunku. Wobec tego, w obu przypadkach większe niż ustawowe odsetki z pożyczki nie są należne, jednakże w pierwszym przypadku zawsze, $w$ drugim dopiero wtedy, gdy ryzyko ustało. Zastaw lub hipoteka nie utrzymują tytułu do większych odsetek.

Powiązanie uprzywilejowanych odsetek z przejęciem przez wierzyciela ryzyka morskiego potwierdzone jest również przez konstytucję cesarzy Dioklecjana i Maksymiana skierowaną do Aurelii Kosmiany:

nary of Greek and Roman Antiquities, William Smith, William Wayte, George Eden Marindin, London 1890 oraz Gothofredus, Codex Theodosianus cum Perpetuis Commentariis, London, Ioannis-Antonni Heuguetan et Marci-Anconii Rauaud 1665, ad C.Th. 2,33,1 oraz Joachim Marquardt, Römische Staatsverwaltung, t. 2, Leipzig 1876, s. 59-62.

${ }^{26}$ W literaturze często przywoływane są w kwestii odsetek Nowele 106 i 110 . Są one niezwykle istotne dla problematyki pożyczki morskiej jednak nie z powodu regulacji odsetek. Cesarz Justynian zezwolił w tej pierwszej na kontynuację zwyczajowych form pożyczek morskich we wschodnich prowincjach, a niecały rok później Nowelą 110 pozwolenie to zostało cofnięte. W żadnym jednak przypadku pobierane zwyczajowo odsetki nie przekraczały wysokości centesimae. 
C. 4,33,3 (Diocletianus et Maximianus Aureliae Cosmianae): Cum dicas pecuniam te e lege dedisse, ut in sacra urbe tibi restitueretur, nec incertum periculum, quod ex navigatione maris metui solet, ad te pertinuisse profitearis, non dubium est pecuniae creditae ultra licitum te usuras exigere non posse. (286 r.)

Skoro mówisz, że pożyczka została dana przez ciebie zgodnie z prawem, aby w cesarskim mieście [Rzymie] została tobie zwrócona, a żadne nieokreślone ryzyko, którego zwykle obawia się przy żegludze morskiej, oświadczyłeś, że nie będzie ciebie dotyczyło, nie ma wątpliwości, że z pożyczonych pieniędzy nie można tobie żądać ponad dopuszczalne odsetki.

Ponadto ta konstytucja, wraz z cytowaną poniżej, stanowią przykłady dawnego prawa, wspominanego przez cesarza Justyniana w C. 4,32,26,2, które dopuszczało odsetki morskie ponad ustawową wysokość centesimae.

\section{4,33,2 (Diocletianus et Maximianus Scribonio Honorato): Traiecticiam pecu-} niam, quae periculo creditoris datur, tamdiu liberam esse ab observatione communium usurarum, quamdiu navis ad portum appulerit, manifestum est. (286 r.)

Jasne jest, że pożyczka morska, która została udzielona na ryzyko wierzyciela, tak długo jest wolna od powszechnych reguł dotyczących odsetek, aż statek zawinie do portu.

O tym, że te charakterystyczne dla pożyczki morskiej odsetki można pobierać tylko wówczas, gdy statek jest na morzu, mówił już przytaczany fragment Pauli Sententiae. Obydwa teksty przekazują pośrednio warunek, który mógłby brzmieć: „od kiedy statek dopłynie, nie możesz pobierać odsetek morskich”. Stąd pojawia się pytanie, jakie ryzyko uzasadniało takie uprzywilejowanie przy pożyczce morskiej.

Dla przyjęcia właściwej perspektywy, należy pamiętać, że obrót dobrami przez morze, eksport i import, mógł z powodzeniem odbywać się bez korzystania z pożyczki morskiej. Podstawowymi umowami transportu morskiego były kontrakt najmu oraz depozyt. Locatio conductio mogła być zawierana w dwojaki sposób: można było wynająć miejsce na statku, a można było umówić się o przewiezienie towaru. W pierwszym przypadku pozycję locator miał magister navis, bo udostępniał cały statek albo jego część; w drugim przypadku osoba, która oddawała swój towar do przewiezienia. Tak tedy za pierwszym razem celem kontraktu było odpłatne udostępnienie określonej przestrzeni ładunkowej. Przewóz morski mógł jednak odbyć się również w oparciu o locatio conductio operis jako locatio conductio mercium vehendarum. Wówczas świadczący tę usługę miał przewieźć rzeczy do określonego portu, a więc zawierano umowę rezultatu o bezpieczne dowiezienie towaru ${ }^{27}$.

${ }^{27}$ Por. Stanisław Kordasiewicz, Receptum nautarum a odpowiedzialność na zasadzie ryzyka, Warszawa 2010 (niepublikowana rozprawa doktorska), s. 50-51. 
Kluczem do odczytania roli pożyczki morskiej może być kwestia odpowiedzialności przewoźników morskich. W kontrakcie najmu odpowiadało się za winę, w depozycie jedynie za podstęp. Niestety, uzależnienie odpowiedzialności tylko od zawinienia przewoźnika rodziło pokusę działania na szkodę klientów, przede wszystkim poprzez wchodzenie przewoźników w zmowę ze złodziejami, na co kupcy niewątpliwie skarżyli się jurystom, którzy uznawali za słuszne zabezpieczenie ich na wypadek podobnych zachowań ${ }^{28}$. Dla zapobieżenia takiej sytuacji pretor wprowadził w edykcie specjalny rodzaj odpowiedzialności przewoźników znany pod średniowieczną nazwą receptum nautarum. Na mocy tego edyktu przewoźnicy odpowiadali za wszelkie zdarzenia, nawet jeśli rzecz została utracona lub uszkodzona bez ich winy. Jedyną przesłankę egzoneracyjną stanowiła siła wyższa ${ }^{29}$. Z punktu widzenia żeglujących eksport i import towarów nigdy nie wiązał się z ich ryzykiem. Przez siłę wyższą tracił ten, kto umawiał się o przewóz. Czemu wobec tego miała służyć pożyczka morska i jakie ryzyko miała zdejmować z dłużnego kupca-żeglarza? $\mathrm{W}$ jakiej sytuacji pieniądze lub towary miały płynąć na ryzyko wierzyciela? Rachunek ekonomiczny najwyraźniej wskazywał, że transport morski wymagał dodatkowego finansowania oprócz wpływów z opłat przewozowych. Pożyczka udzielana przewoźnikowi dawała większą swobodę podejmowania działalności gospodarczej, umożliwiając mu bezpieczne ekonomicznie planowanie i zorganizowanie wyprawy: wyposażenie statku, zatrudnienie załogi, zakup towarów, zapłatę podatków, wypłatę ewentualnych odszkodowań.

W literaturze spotyka się kilka hipotez na temat funkcji oraz charakteru pożyczki morskiej. W świetle jednej z nich, ewolucja rzymskiego prawa kontraktów oparta była na rozpoznaniu praktycznego sensu zobowiązania i wzajemnego rozkładu ryzyka. Odstępstwo od ogólnych zasad kontraktu pożyczki, podyktowane było bardziej racjonalnymi ekonomicznie regułami odpowiedzialności kontraktowej podmiotów finansujących transport morski, przez których udzielana pożyczka była określana właśnie jako pecunia traiecticia ${ }^{30}$. Kolejna hipoteza $\mathrm{w}$ istocie rozbudowuje to podejście. Podkreśla bowiem, że przy typowej pożyczce dłużnik pozostawał zobowiązany, nawet jeśli stracił to, co otrzymał na skutek siły wyższej: pożaru, trzęsienia ziemi lub katastrofy morskiej statku. W przypadku pożyczki morskiej otrzymane pieniądze miały być dane na ryzyko wierzyciela. Celem takiego zabiegu było uzyskanie przez kupca-żegla-

${ }^{28}$ Por. D. 4,9,1,1 (Ulpianus libro quarto decimo ad edictum): nam est in ipsorum arbitrio, ne quem recipiant, et nisi hoc esset statutum, materia daretur cum furibus adversus eos quos recipiunt coeundi, cum ne nunc quidem abstineant huiusmodi fraudibus (ponieważ jest $\mathrm{w}$ ich mocy podjęcie decyzji, by czegoś nie przyjąć, i gdyby nie było tego edyktu, istniałaby możliwość współdziałania ze złodziejami na szkodę innych osób, których rzeczy zostały przyjęte na statek, ponieważ nawet teraz nie powstrzymują się od podobnych oszustw - thum. S. Kordasiewicz, Receptum nautarum..., s. 94).

${ }^{29}$ Por. D. 4,9,3,1 (Ulpianus libro quarto decimo ad edictum).

${ }^{30}$ W. Dajczak, T. Giaro, F. Longchamps de Bérier, Prawo rzymskie..., s. 516-517. 
rza, operującego na trasach morskich, potrzebnych środków na to, aby zakupić towary i przewieźć je na własny rachunek. R. Zimmermann wskazuje, że jednak niebezpieczeństwo utraty tych środków było tak prawdopodobne, że kupiec-żeglarz poszukiwał swego rodzaju ubezpieczenia od ryzyka morskiego ${ }^{31}$. Tę funkcję spełniała pożyczka morska, skoro pieniądze miały być oddane tylko wtedy, gdy statek dotarł szczęśliwie do portu z towarem na pokładzie ${ }^{32}$. Wierzycielowi przejmującemu ryzyko wyprawy kupca-żeglarza, pozwalano pobierać odsetki do czasów Justyniana w ogóle nie limitowane, których nie uważano za lichwiarskie, ponieważ nie stanowiły w opinii Rzymian wynagrodzenia za używanie cudzego kapitału. Były one pretium periculi - odpowiednikiem przejęcia ryzyka, czy też dosłownie ceną ryzyka ${ }^{33}$.

Jeszcze dalej idzie koncepcja, która polemizuje z tradycyjnym już poglądem, że funkcja ubezpieczeniowa stała się produktem ubocznym pożyczki udzielanej kupcowi-żeglarzowi, któremu brakowało kapitału. Pożyczka mogła być udzielana przecież i wówczas, gdy dokapitalizowanie nie okazywało się całkowicie konieczne. Wtedy jednak właściciel statku czy kupiec-żeglarz chcieli ubezpieczyć się na wypadek niebezpieczeństw morskich, a pożyczka była tylko środkiem do osiagnnięcia tego celu. W ten sposób miano połączyć ubezpieczanie własności ze „złotą zasadą prowadzenia interesów”, za którą uważa się współpracę i ryzykowanie cudzych pieniędzy ${ }^{34}$.

Ostatnio Z. Benincasa postawiła jeszcze inną hipotezę, że pożyczka morska stanowiła sposób ograniczania ryzyka związanego z podróżami morskimi poprzez podzielenie się nim $\mathrm{z}$ innymi osobami w ramach wspólnie prowadzonego przedsięwzięcia ${ }^{35}$. Finansujący przyjmował ryzyko utraty środków, a pożyczkobiorca ryzyko nawigacji. W ten sposób, obok pieniędzy, we wspólną inwestycję zaangażowany był osobisty wkład dłużnika, a nawet utrata przez niego życia ${ }^{36}$. Trudno jednak uznać, że śmiertelność w morskich wyprawach była tak powszechna, jak sama obawa przed żywiołem, w innym wypadku ówczesny handel śródziemnomorski nie osiagnąłby dosyć wysokiego stopnia rozwoju ${ }^{37}$. Szczęśliwe zakończenie podróży dawało zysk obu stronom - dłużnikowi w postaci dochodu ze sprzedanego towaru, a wierzycielowi z tytułu wypłaconych mu przez kupca-żeglarza odsetek, o jakie umówił się bez prawnego ograniczenia ich wysokości. Potwierdzać ma to również niezwykłe zaangażowanie wierzyciela w sposób prowadzenia żeglugi: mógł określać w umo-

${ }^{31}$ Reinhard Zimmermann, The Law of Obligations. Roman Foundations of the Civilian Tradition, Cape Town, Wetton, Johannesburg 1992, s. 181.

${ }^{32}$ Ibidem, s. 182.

${ }^{33}$ Ibidem.

${ }^{34}$ Phillip J. Thomas, Insurance in Roman law: Martialis Epigrammaton III 52, „Journal of South African Law" (TSAR) 2009 nr 2, s. 267.

${ }^{35}$ Z. Benincasa, Periculi..., s. 249.

${ }^{36}$ Co ciekawe, św. Paweł przeżył 3 katastrofy morskie.

${ }^{37}$ Ibidem. 
wie czas lub trasę. Ponadto posyłał swoich niewolników, którzy świadczyli usługi, opłacane przez dłużnika. Z. Benincasa zauważa, że wyjaśnieniem takiej działalności może być przypuszczenie o ukrytym prowadzeniu ryzykownych interesów morskich przez osoby z wyższych sfer, którym nie uchodziło angażować się w tego typu przedsięwzięcia. Podaje, że argumentem za tym nastawieniem społecznym mogą być plebiscitum Claudianum, lex de repetundis $\mathrm{Ce}-$ zara oraz to, że w rzymskiej mentalności zyski z handlu morskiego nie były uważane za pius quaestus ${ }^{38}$. Prawdziwym inwestorem był zatem wierzyciel, który dostarczał pieniędzy na realizację wspólnego przedsięwzięcia, decydował o jego przebiegu i zakresie oraz na bieżąco kontrolował wykonanie, niekiedy angażując $\mathrm{w}$ to swojego agenta ${ }^{39}$. W tym rozumieniu kontrakt pożyczki morskiej był odmianą współdzielenia ryzyka, podobnie jak w przypadku spółki cywilnej. Natomiast w swojej istocie dla pożyczkodawcy stawał się umową losową - emptio spei, gdyż oddanie pożyczki pozostawało w dużej mierze zależne od dłużnika i od szczęścia.

Wydaje się, że w obliczu różnych hipotez warto sięgnąć do przekazu zawartego w Noweli 106, który może okazać się pewną pomocą dla zrozumienia myśli rzymskiej. Justyniańscy juryści musieli odnieść się w niej do innych modeli umowy pożyczki morskiej. Różne jej modyfikacje, praktykowane w prowincjach wschodnich, zostały zaakceptowane jako zgodne z regulacją prawa rzymskiego. Jednak już w Noweli 110 zakazano ich, bez podania żadnej merytorycznej przyczyny, i stwierdzono, iż przestały być prawnie skuteczne. Nie umniejsza to wagi przekazu z Noweli 106, a raczej skłania do zastanowienia się nad przyczynami tak nagłej zmiany stanowiska. Kwestia regulacji pożyczki morskiej musiała być niewątpliwie istotna, skoro prawodawcy justyniańscy poświęcili jej tak wiele miejsca w pierwszej z cytowanych Nowel. Uszanowanie rządzących nią zwyczajów prawdopodobnie stanowiło drażliwy temat, szczególnie we wschodniej części cesarstwa, będącej ośrodkiem handlu morskiego. Stąd łatwo wyczuć niezwykle spolegliwy ton Noweli 106.

N. 106 pr. Nuntium audivimus a tua celsitudine, cui occasionem nos ipsi praebuimus. Docuisti enim Petrum et Eulogium supplicasse sacrae nostrae potestati et per se explanasse dicentes, quia consueverunt naucleris seu negotiatoribus mutuare aurum et maxime in mari negotia facientibus, et hanc habere vitae occasionem (ipsa vero marina credita vocare nostra consuevit lex traiecticia), et metuere eos utpote dubitationibus hinc eis exortis; oportere propterea ferii manifestum, quae valeat super his consuetudo, ut et sacra nostra in hoc procederet iussio quae consuetudinem ad certissimam duceret formam. Itaque nos delegasse tibi dubitationis naturam cognescere et hanc ad nos deducere, quatenus manifesta nobis facta quo videretur lege comprehenderetur perpetua; tuamque gloriam haec a nobis agere iussam

${ }^{38}$ Ibidem, s. 252.

${ }^{39}$ Ibidem. 
convocasse naucleros quibus haec mutua curae sunt, et interrogasse, quae aliquando antiqua consuetudo fuit; illos autem et iusiurandum adicientes testimonium perhibuisse, modos esse varios talium mutuorum, et si quidem placuerit creditoribus, in singulis solidis pecuniarum quas dederint unum tritici modium aut hordein imponere, neque mercedem publicis praebere pro eo teloneariis, sed quantum ad ipsos sine teloneo navigare naves, et hunc habere fructum earum quas crediderunt pecuniarum, et insuper etiam per decem aureos unum percipere solum pro usuris, in ipsos autem creditores respicere ex eventibus periculum. Si vero non sumant hanc via creditores, octavam partem percipere pro singulis solidis nomine usurarum non in tempus aliquod certum numerandam, sed donec naves revertantur salvae. Secundum hoc autem schema contingit forsan et in annum extendi tempus, si tantum foris moretur navis ut et annum aut terminos sumat aut etiam transcendat, citius autem ea remeante tempus in unum solum aut duos trahi menses, et ex tribus siliquis utilitatem habere, vel si ita breve sit tempus vel si apud alterum extra debitorem maneat debitum. Hoc idem valere aliam rursus negotiatoribus profectionem assumentibus, et per unumquodque onus definiri schema secundum quod competat mutuum aut manere aut permutari secundum pactum quod ob hoc convenerit partibus. Si tamen post reversionem navis salvae et nequaquam navigare propter tempus valentis revertantur, viginti et solum dierum indutias dari a creditoribus debitoribus, et nihil pro debitis usurarum causa exigere, donec vendi contingat onus; parcentes apud alium esse debitum non reddendum, duas partes centesimae dominis pecuniarum dare usuras, et mutare mox mutuum et in terrenum transponere modum, nequaquam maritimis periculis creditorem molestantibus. Et haec omnes dixisse cum iureiurando perhibentes testimonium. Quae ad nos nuntiasti, ut nos sanciremus quod nobis videretur, et super his dicebas haec nostrae nuntiata potestati.

1. Nos igitur et ipsa legentes gesta et causam edocti sancimus secundum quod testatum est coram tua celsitudine ita nunc et deinceps in omne tempus tenere, eо quo neque iam positis repugnant legibus, ut oporteat nunc et de cetero secundum quandam propriam legem in nauclericis aut negotiatoriis super talium causarum haec servari litibus, et secundum dictum modum praedictarum pactionum ita fieri etiam eventus et alia omnia quaecumque in prioribus testata sunt apud sedem tuam, unde secundum propriam legem teneant in nauclericis aut negotiatoriis. Quod enim longis ita servatum est temporibus et tenuit immutabiliter, sicut testimonia apud tuam gloriam definierunt, quomodo non est iustum et in aliis omnibus valere quae postea erunt, et esse hanc eis rerum transactionem ex propria lege valentem et altera quadam dispositione non egentem, sed in nauclericis seu negotiatoriis occasionibus in omne tempus valentem, utpote generalem existentem legislationem et in nauclericis seu negotiatoriis contractibus expositam, et quae debet etiam pars fieri iam a nobis positarum legum, et iudicantes ad hanc respicientes proferre sententias.

$<$ Epilogus.> Quae igitur placuerunt nobis tua celsitudo iugiter servare festinet. (540 r.)

Wysłuchaliśmy wiadomości od Twojej wysokości, i ten przypadek do nas sami dopuściliśmy. Mianowicie pouczyłeś Piotra i Eulogiusza, aby zanosić prośby do 
naszego cesarskiego urzędu i przez siebie wyjaśnić, to co przedstawiane, ponieważ właściciele statków [przewoźnicy] i kupcy mają w zwyczaju pożyczać pieniądze, a szczególnie podejmując przedsięwzięcia na morzu, i mając ten powód, [że to ich] sposób życia (rzeczywiście same pożyczki morskie nasze prawo nawykło nazywać traiecticia), i bojąc się mianowicie pojawiających się stąd wśród nich wątpliwości. $Z$ tego powodu należało podać publicznie wiadomość o tym zwyczaju, który jest prawnie skuteczny, aby i nasze cesarskie polecenie ukazało się w tym względzie, które doprowadziłoby zwyczaj do najpewniejszej postaci. I wobec tego my delegowaliśmy Ciebie, abyś poznając naturę wątpliwości i nam ją ujawniając, uczynił przed nami jasnym, co byłoby właściwe, aby powszechne prawo obejmowało. I Twoją chwała, czyniąc to dla nas, zwołałeś rozkazem właścicieli statków [przewoźników], którzy zajmują się tymi pożyczkami, i przesłuchałeś, jaki dawny zwyczaj niegdyś istniał. Oni natomiast złożyli świadectwo dodając przysięgę, że wyróżniane były rozmaite sposoby pożyczania, i jeśli mianowicie podobało się wierzycielom, nakładali na każdy solid z pożyczek, które dawali, jedną miarę zboża lub jęczmienia, i nie przeznaczając na publiczną daninę tam dla celników, lecz, ile wartą [pożyczkę], bez cła, przewożąc statkami. Mieli tu pożytek z tych, które pożyczyli w pieniądzach, i ponadto jeszcze z dziesięciu aureusów jeden tylko pobierali tytułem odsetek, ich natomiast dotyczyły konsekwencje ryzyka. Natomiast, jeśli wierzyciele nie pożyczają w ten sposób, pobierają ósmą część każdego pożyczonego solida tytułem odsetek, bez wyliczonego jakoś ściśle czasu [pożyczki], lecz aż statek powróci nienaruszony [szczęśliwie]. Natomiast według tej postaci udzielanej [pożyczki], okres może się rozciągnąć i na rok, a nawet jeśli statek tak bardzo zwlekał, że okres roku lub termin pożyczki został przekroczony. Natomiast jeśli czas pozostawania był krótki i nie zwlekał dłużej niż jeden lub dwa miesiące, mieli korzyść z trzech silikwii ${ }^{40}$ [sykli] lub jeśli czas tej [podróży] był bardzo krótki lub jeśli na innego ponadto dłużnika przeniósł dług. To zaś obowiązuje, gdyby kupcy z powrotem podjęli inną podróż, że dla każdego jednego jest określana postać obowiązku [zapłaty odsetek], zgodnie z tym, czy należy się z pożyczki czy zostało przeniesione czy wymienione [z innym] poprzez pactum, które zostało zawarte między stronami. Lecz po szczęśliwym powrocie statku, gdy w żaden sposób nie mógłby wyruszyć z powrotem ze względu na silną burzę, wierzyciele dają dłużnikom tylko dwadzieścia dni zwłoki i o nic z tytułu dłużnych odsetek się nie domagają, aż nie zostanie sprzedany przyjęty ładunek. Cierpliwie nie będą zwracać długu wobec innego, aż oddadzą wierzycielowi z pożyczki dwie części [1/2] centesimae tytułem odsetek, i natychmiast zmienią pożyczkę i przeniosą ją na obszar ziemi [zamienią na ten rodzaj udzielany na lądzie], tak że w żaden sposób wierzyciele nie będą niepokojeni ryzykiem morskim. I to wszystko zostało powiedziane w świadectwie pod przysięgą. To, co do nas zanosiłeś, abyśmy zatwierdzili, jak nam zostało przedstawione, nad tym, co powiedziałeś, rozciągnęła się nasza władza.

${ }^{40}$ Siliqua, jak aureus, to moneta, tyle że srebrna, wprowadzona przez Konstantyna w 309 r. po Chr. 
1. Zapoznawszy się sami z zebranymi działaniami i przyczynami, zatwierdzamy, zgodnie z tym, co zostało zaświadczone dzięki Twojej wysokości, aby od teraz i w przyszłości, w każdym czasie wiązało, ponieważ nie sprzeciwia się to już ustanowionym prawom, tak że ma być wypełniane teraz i później jako właściwe prawo dla właścicieli statków [przewoźników] i kupców, gdy z powodu wypełnienia tego rodzaju zobowiązania będą prowadzić procesy, i niech zgodnie z tym właściwym prawem dla właścicieli statków [przewoźników] i kupców, będą czynione spodziewane tego rodzaju umowy o ryzyko i według wszystkiego pozostałego, cokolwiek we wcześniejszych sprawach było zaświadczone przed Twoim sądem. To, co mianowicie służyło przez tak długi czas i pozostało niezmienne, określone według świadectw przed Twoją wysokością, w żaden sposób nie jest słuszne, aby nie pozostało prawnie wiazzące we wszystkich innych sprawach, które były później, i nie może być, aby potrzebowało szczególnego prawa dla swojej prawnej ważności w przedmiocie, którego dotyczy, lecz w sprawach dotyczących przewoźników i kupców, powinno być postrzegane jako zawsze wiążące prawo, jako że było istniejącym powszechnym prawem i umowom przewoźników i kupców przychylnym, i stąd powinno być uznane za część przez nas ustanowionego prawa, i sędziowie powinni zmienić wcześniejsze wyroki.

Epilog. Zatem podoba się nam, aby Twoja wysokość niezwłocznie i stale tego strzegła.

Warto przytoczyć również, niezwykle krótką, Nowelę 110 wydaną zaledwie niecałe osiem miesięcy później ${ }^{41}$, która odwołała tę zacytowaną powyżej.

W swojej formie również stanowi jej całkowite przeciwieństwo:

N. 110 pr. Novimus ex denuntiatione tuae celsitudinis legem iam fecisse de traiecticiis pecuniis, quae manifesta facta est foro tuo.

1. Sed quoniam postea aditionibus nobis factis praecepimus legem illam non valere, resumi eam imperantes ex foro tuo, agnovimus autem eam et in quibusdam provinciis iam insinuatam, propterea sancimus talem legem omnino vacare, et si contigit etiam per provincias eam destinari, nec ibi valere, sed invalidam esse. Sic enim volumus causam procedere, tamquam si nec scripta fuisset memorata lex, sed secundum iam de talibus positas leges a nobis negotia examinationem et sententiam potiantur.

$<$ Epilogus. $>$ Quae igitur placuerunt nobis et per hanc sacram declarata sunt legem, tua celsitudo operi effectuique contradere festinet. (541 r.)

Dopiero uznaliśmy, na zawiadomienie Twojej wysokości, prawo dotyczące pożyczek morskich, które Tobie oznajmiono.

Lecz, skoro później przychodzono do nas [z prośbami], postanowiliśmy, że to prawo nie jest skuteczne, zarządzając, iż ma być wycofane z Twojego sądu, natomiast

${ }^{41}$ Nowela 106 została wydana w idy wrześniowe 540 r. po Chr., a Nowela 110 w kalendy majowe 541 r. po Chr. 
dowiedzieliśmy się, że zostało ono już wprowadzone także w niektórych prowincjach, przeto postanawiamy, że tego rodzaju prawo całkowicie nie ma mocy prawnej, i jeśli spotka się jeszcze, że jest przeznaczone dla [innych] prowincji, i tam nie wiąże, lecz jest całkowicie bezskuteczne. Tak mianowicie chcemy, aby postępowano, jak gdyby nigdy nie napisane było to wspomniane prawo, lecz według tych praw, które już zostały ustanowione przez nas, sprawy były badane i rozstrzygane. Epilog. Zatem podoba się nam, aby Twoja wysokość niezwłocznie wykonała i uczyniła skutecznym to cesarskie prawo, które zostało ogłoszone.

Zgodnie z opisaną w Noweli 106 praktyką wierzyciel miał do wyboru trzy rodzaje pożyczki morskiej. Pierwszy polegał na umówieniu się, że w zamian za otrzymane pieniądze dłużnik będzie świadczył oprócz głównej sumy: odsetki w wysokości 10\% (1 aureus na dziesięć pożyczonych) oraz jedną miarę zboża lub pszenicy za każdego solida. Ponadto, wierzyciel nie ponosił opłat portowych za odbywający się w ten sposób transport morski. Natomiast przyjmował na siebie ryzyko przyszłych zdarzeń. Według drugiego sposobu wierzyciel otrzymywał 12,5\% (ósmą część każdego solida, tj. 3 silikwie) tytułem odsetek, za pożyczkę udzieloną na nieokreślony czas żeglugi, aż do momentu, gdy statek szczęśliwie wróci. Niezależnie od tego, czy będzie trwała rok lub nawet więcej, czy też miesiąc lub dwa, jeśli statek wróci, wierzyciele otrzymają swój zysk. Podobnie przyjmuje się, gdy podróż trwała jeszcze krócej lub gdy kupiec przeniósł pożyczkę na innego dłużnika. Natomiast trzeci rodzaj miał miejsce wtedy, gdy dłużny kupiec w drodze powrotnej podjął nową wyprawę. Wówczas pobierano albo tę stawkę odsetek, która obowiązywała w umowie albo, w sytuacji gdy nastąiło przeniesienie pożyczki na nowego kupca, tę zawartą w postanowieniach pactum.

Elastyczność posługiwania się pożyczką morską we wschodnich prowincjach stanowi świadectwo niezwykle rozwiniętego rynku handlowego, w którym zarabianie na ryzyku wydawało się jedną z powszechniejszych form działalności. Być może głosy niezadowolenia, które doszły do cesarza Justyniana, są dowodem na istnienie niezbadanej dotąd rywalizacji różnych środowisk kupieckich. Za tak nagłym uchyleniem Noweli 106, niemal wysławiającej zwyczajowe pożyczki morskie, przez bardzo lakoniczną Nowelę 110, musiało kryć się duże napięcie społeczne. Źródła niestety nie dostarczają wystarczających danych, aby odtworzyć w pełni tę sytuację i poznać rzeczywiste powody zmiany zdania przez cesarza. Niestety również późniejsza tradycja prawa średniowiecznego i nowożytnego nie zainteresowała się okolicznościami tych wydarzeń. Jedynym punktem zaczepienia pozostają przedstawione konstrukcje pożyczki morskiej. Porównując je z rzymską pecunia traiecticia, już teraz można zauważyć, że Nowelą 106 wprowadzone zostały instrumenty posiadające o wiele bardziej spekulacyjny charakter. Chodzi o niektóre umowy zawierane według drugiego i trzeciego sposobu. Natomiast pierwszy typ po- 
życzki morskiej był przykładem wykorzystania tego kontraktu do wspólnej realizacji przedsięwzięcia. Wierzyciel udzielał środków finansowych, otrzymywał odsetki, a do tego oznaczona była wielkość jego udziału w zyskach $\mathrm{z}$ handlu dobrami ${ }^{42}$. Z tego powodu, nie była to „czysta” rzymska pożyczka morska, choć bardzo zbliżała się do koncepcji Z. Benincasa.

Wśród umów z drugiej kategorii odnaleźć można również odpowiednik pecunia traiecticia, tj. pożyczanie pod warunkiem szczęśliwego dopłynięcia stat$\mathrm{ku}$ oraz z wyznaczaniem czasu trwania żeglugi. Z punktu widzenia prawa rzymskiego wątpliwości zaś budzą: przeniesienie pożyczki na innego kupca oraz dozwolona zmiana trasy podróży powrotnej. Obydwie nadmiernie zwiększały ponoszone przez wierzyciela ryzyko. Wydaje się, że w obliczu ciagłych zabiegów o względną kontrolę nad dłużnikiem, które dostrzega się w źródłach rzymskich, taka swoboda oznaczałaby grę prawie „czystym ryzykiem”, a więc nadmierną spekulację, nawet jeżeli strony godziły się na nią. Ciekawe jest jednak, że nawet te umowy uznano początkowo za dopuszczalne. Być może przyczyną wprowadzenia zakazu stały się, nie rozważone wcześniej, a jednak niepożądane przez cesarza ich skutki społeczne lub ekonomiczne: zbyt ryzykowne inwestycje, nagłe bankructwa itp.

V.Śmierć pożyczki morskiej? Przedstawiono kilka hipotez na temat okoliczności, w jakich posługiwano się pożyczką morską i funkcji, które miała wypełniać w prawie rzymskim. Już na podstawie dotychczasowych rozważań nasuwają się pewne wnioski. Przede wszystkim można mówić o dwoistym, pieniężnym i towarowym, charakterze pożyczki od początku posługiwania się nią. Ponadto o większej roli niż tylko finansowanie transportu morskiego. Zwyczaj przyjmowania w zastaw transportowanych towarów, nabytych za tę pożyczkę, świadczy, że jedynym uzasadnieniem dla uprzywilejowanych odsetek było przejęcie pełnego ryzyka podróży morskiej. W ten sposób pecunia traiecticia zaczyna jawić się jako umowa łącząca w sobie rozsądną spekulację ryzykiem oraz ubezpieczanie inwestycji handlowych. Wierzyciel przejmował na siebie ryzyko utraty pożyczonych pieniędzy w ten sposób, że albo otrzymywał bardzo duży zysk: kwotę pożyczki wraz z wysokimi odsetkami, albo tracił cały zainwestowany kapitał. Jakiekolwiek zastawy na statku lub towarach w momencie katastrofy przestawały zabezpieczać wierzytelność. Dlatego można mówić, że kontrakt ten służył grze dużym ryzykiem, a finansujący transport zobowiązany był przejąć na siebie całe niebezpieczeństwo związane z podróżą.

\footnotetext{
${ }^{42}$ Rozróżnienie umów pożyczki morskiej i umów służących prowadzeniu wspólnej działalności było również obecne w tradycji prawa islamskiego. Por. Hassan S. Khalilieh, Admirality and Maritime Laws in the Mediterranean Sea (ca. 800-1050), w: The Medieval Mediterranean Peoples, Economies and Cultures, 400-1500, red. Hugh Kennedy, Paul Magdalino, David Abulafia, Benjamin Arbel, Mark Meyerson, Larry J. Simon, t. 64, Brill Leiden-Boston 2006, s. 228, 232, 243, 246-247.
} 
Rzymska koncepcja pożyczki morskiej przetrwała w glosach, komentarzach i opracowaniach średniowiecznych i nowożytnych. Ostatni raz można ją spotkać w dziewiętnastowiecznych komentarzach do common law, gdzie przyjmuje nazwę usura maritima lub fenus nauticum. W czasie rozwoju zachodniej tradycji prawnej rozszerzono jej zastosowanie na podróże odbywane w celach handlowych przez niebezpieczne ziemie, nazywając taką umowę fenus quasi nauticum. Jednak pecunia traiecticia nie zawsze była wykorzystywana w praktyce. Aż do XII wieku w ogóle się o niej nie wspominało. Motorem napędowym jej odrodzenia były ważne zmiany ekonomiczne. Ponowne rozpowszechnienie gospodarki towarowo-pieniężnej oraz rozbudzenie handlu śródziemnomorskiego, również dzięki wyprawom krzyżowym, przypomniało prawnikom i kupcom o dawnym rzymskim pomyśle. Później momentem przełomowym były wielkie odkrycia geograficzne i podejmowanie wypraw handlowych o ryzyku do tej pory nieznanym. W ten sposób stworzony został ogromny rynek, który w sposób stabilny rozwijał się aż do XIX wieku, aby wówczas przeżyć kolejną zmianę, związaną z wynalazkami, doskonaleniem techniki transportu i zmniejszaniem ryzyka podróży. Okazało się, że rzymska pożyczka morska nie była już tak potrzebna jak dawniej, co doprowadziło do jej całkowitego zaniku. Czy pecunia traiecticia jest zatem ślepą uliczką w tradycji prawnej?

Wydaje się, że nie. Warto zwrócić uwagę na wyróżnione dwa sposoby zawierania umowy: pod warunkiem albo pod warunkiem z dołączonym terminem żeglugi. Pierwszy z nich świadczy o tym, że pożyczka miała pełnić funkcję ubezpieczeniową. Liczyło się bowiem szczęśliwe zakończenie wyprawy. Dłużnik zabezpieczał się przed nieoczekiwanymi zdarzeniami, w tym wypadku - związanymi z niebezpieczeństwem podróży morskiej. Dzięki temu, wskutek katastrofy jego strata nie stawała się większa - nie musiał oddawać pożyczki wraz z odsetkami. Poza tym wszystko, co ocalało, należało się właśnie dłużnikowi. Nie należy jednak sądzić, że Rzymianie znali już umowę ubezpieczenia. Podobnie jak w dzisiejszych czasach ubezpieczanie się może być realizowane przez różne rodzaje kontraktów. Przed stratami ekonomicznymi wynikającymi z wahań cen lub kursów walut można się zabezpieczać przez umowy opcji, wykorzystywane są umowy futures, forward czy hedge. Nikt nie nazywa ich umowami ubezpieczenia, lecz w swojej istocie, jedna strona ryzykuje, aby druga nie poniosła zbyt dużych strat. Oczywiście, te współczesne umowy nie są kopią pożyczki morskiej, lecz upodabniają się do niej w swoim podejściu do zabezpieczania się od ryzyka. Także pecunia traiecticia była bowiem w pewnym sensie ,zakładem”: dopłynie albo nie dopłynie. Strony umowy wydawały się jednak stać na równorzędnych pozycjach, co potwierdza brak roszczeń wierzyciela do tego, co ocalało z katastrofy. Tak naprawdę transport morski mógł być wyłącznym przedsięwzięciem dłużnika, poszukiwał on tylko odpowiednich środków na jego realizację. Wierzyciele dostrzegli w tym szan- 
sę na pomnażanie swoich dochodów bez większego wysiłku i w miarę krótkim czasie.

Ryzyko, jakie podejmowali, nie było jednak czystą spekulacją. Musiało być roztropnie rozpoznane. Dlatego wyznaczano trasy żeglugi, miejsca, gdzie miały być kupione lub dowiezione towary. Wierzyciele wysyłali swoich niewolników, aby pilnowali wykonywania umowy i liczenia dni żeglugi. Nie chcieli być zdani wyłącznie na drugą osobę lub siły przyrody. Pragnęli mieć pewną kontrolę, aby nie narażać się na lekkomyślne straty. Stąd ciekawy wydaje się drugi sposób zawierania pożyczki morskiej. Wyznaczenie terminu żeglugi sprawiało, że cel, jakim było szczęśliwe dopłynięcie przestawał mieć znaczenie. Liczyło się zarabianie na przejęciu ryzyka przez określony czas.

Zatem pecunia traiecticia nie pozostała wyłącznie starożytnym pomysłem, lecz kwitła w swojej dawnej postaci aż do XIX wieku. W obecnych czasach być może ryzyko morskie zostało ujarzmione, a o wiele istotniejsze staje się poszukiwanie zabezpieczenia przed niespodziewanymi zmianami ekonomicznymi. Nie jest jednak wykluczone, że rzymska pożyczka morska może powrócić. Jej siła jest mechanizm całkowicie zrozumiały dla współczesnego człowieka: słuszne wynagrodzenie za przejęcie ryzyka. 